Authors' Contribution:

A - Study Design

B - Data Collection

C - Statistical Analysis

D - Data Interpretation

E - Manuscript Preparation

$F$ - Literature Search

$\mathrm{G}$ - Funds Collection

\section{The Level of Physical Development and Physical Fitness in 6-7-Year-Old Children from School and Pre-School Institutions in Gdansk}

\author{
Małgorzata Resiak $^{1}(\mathrm{~A}, \mathrm{C}, \mathrm{D}, \mathrm{E}, \mathrm{F})$, Aleksandra Niedzielska ${ }^{2}$ (B, E) \\ ${ }^{1}$ Gdansk University of Physical Education and Sport in Gdansk, Poland \\ Promotion of Health Department \\ ${ }^{2}$ Promotion of Health and Child's Fitness Center in Gdansk, Poland
}

Key words: physical development, physical fitness, children, school, pre-school

Material/Methods: 15,578 children (8,006 boys and 7,572 girls) from Gdansk were subject to research in

\title{
Abstract
}

Background: Interest in the development of a 6-7-year-old child derives among other things from the necessity to evaluate child's readiness to take up a regular educational process. Physical development and physical fitness of the child are components of school maturity.

The purpose of the study was to show similarities and differences in the level of physical development and fitness of children attending school and pre-school institutions in the years 2005-2009 in Gdansk.

the years 2005-2009. The measurements of the height, body mass and 5 skin folds were carried out. BMI and \%BF were calculated. To determine the physical fitness level, the following tests were applied: sit and reach, standing broad jump, sit-ups and a 3-min step-test.

Results: In pre-schools children higher values of body height were observed in the investigated period (2005-2009) but, at the same time, there were no differences in body mass between children from pre-schools and schools. Nor did the children differ in the amount of fat deposition. In the fitness level the biggest differences between the results achieved by children from schools and pre-schools were noted in the test of standing broad jump on both feet. Both boys and girls from pre-schools got higher scores in this test and their post-effort HR was lower in comparison with their peers from schools.

Conclusions: Differences in the level of physical fitness, especially its manifestations depending on everyday physical activity, reflect well on conditions created for children in preschools.

Word count: 3,135

Tables: 9

Figures: 0

Received: October 2011

References: 20 


\section{Introduction}

Interest in the development of a 6-7-year-old child derives, among other things, from the necessity to evaluate child's readiness to take up a regular educational process.

So far, if a six-year-old has fulfilled norms of school maturity, the parents could make a decision to send their child to school earlier. If the child did not begin his/her education in the first grade of primary school, participation in the "0 class" organized at school or pre-school institutions has been obligatory since 2004. From 2014 all six-year-olds will have to start their primary education at school.

School maturity is a notion which covers physical, psychological and social aspects of a child's development. According to S. Szuman [1], "school maturity is the state in which the level of physical, social and psychological development makes a child sensitive and susceptible to systematic education and teaching."

The assessment of school maturity is an interdisciplinary issue. Appropriate physical development, which undoubtedly is a primary condition to achieve such maturity, proceeds differently in boys and girls. It is a process within the child's body, which consists in achieving quantitative (growth) and quality features (diversification) and improving the structure and function of particular organs and systems (maturity) [2]. A part of physical development is a somatic development, most often described through the height and body weight.

Development of physical fitness and capacity is a function of physical development [3]. It is also an indisputable positive measure of health $[4,5,6]$ and school maturity $[7,8]$.

School readiness is achieved by a child under concrete financial and social conditions. It is made of various, gained in a particular child's environment, experiences in the motor, intellectual, emotional and social spheres [9]. In the present study we took one of the factors of the environment into consideration: the place of participating in education - the school or pre-school. In 2006 a report from nationwide research on 6-year-olds was published [10]. Authors of this research observed a higher level of motor abilities in children attending schools. However, they did not claim differences in motor development which would dependent on the kind of educational institution (school or pre-school). As it was a one-time study, it is worth validating this problem based on longer observations.

The purpose of the study was to show similarities and differences in the level of physical development and fitness of children attending school and pre-school institutions in the years 20052009 in Gdansk. Since, irrespective of where this process takes place, the same curriculum is required and similar stimuli should affect the child, thus the occurrence of significant differences in the level of physical development and fitness in the subjects is not assumed.

\section{Material and Methods}

15,578 children ( 8,006 boys and 7,572 girls) from Gdansk were subject to research in the years 2005-2009. Table 1. presents the number of groups in particular years.

Tab. 1. Number of examined boys and girls in particular years

\begin{tabular}{cccc}
\hline Year & Boys $(\mathrm{n})$ & Girls $(\mathrm{n})$ & Total $(\mathrm{n})$ \\
\hline 2005 & 1,702 & 1,684 & 3,386 \\
2006 & 1,686 & 1,498 & 3,184 \\
2007 & 1,457 & 1,454 & 2,911 \\
2008 & 1,705 & 1,530 & 3,235 \\
2009 & 1,456 & 1,406 & 2,862 \\
Total & 8,006 & 7,572 & 15,578 \\
\hline
\end{tabular}

The arithmetic mean of the subjects' age was $6.6(0.4)$ years. Children participated in the research after previous approval of the pediatrician. Body height and weight measurements followed the requirements [11]. BMI was calculated according to the formula: body weight $(\mathrm{kg}) / \mathrm{body}$ height $^{2}\left(\mathrm{~m}^{2}\right)$. 
Skin-folds measurements were conducted on: above biceps brachii and triceps brachii, below the spatula, above the iliac spine and on the internal side of the calf. These measurements had to satisfy the requirements and were carried out by a Lange caliper, on the left side of the body [12]. The percentage of the fatty tissue was calculated (\%BF) according to the formula [13]:

$$
\% \mathrm{BF}=\left[\frac{4.95}{G}-4.5\right] \times 100 \%
$$

Body density $(G)$ was calculated according to the following formulas [14]:

- for boys $1.1533-0.0643 \times \log \sum 4$ folds ${ }^{1}$

- for girls $1.1369-0.0598 \times \log \sum 4$ folds

In the presence of parents and with their approval, motor tests and a step-test were carried out. To determine the fitness level the following tests were performed: sit and reach, standing broad jump, and sit-ups. To evaluate physical capacity, included here in physical fitness, a 3-minute step test (height of the step $=30.5 \mathrm{~cm}$, pace -24 up/down steps per min) was applied. Post-effort average HR determined the capacity index $[15,16]$. This frequency was registered for a minute in a sit, few seconds after the effort at the latest, with the use of sport-tester PE 3000.

\section{Results}

The results were put in tables considering the gender, kind of educational institution (preschool/school) and the year of the research. In tables 2-5 somatic developmental data of children are presented.

Tab. 2. Numerical description of body mass in boys and girls

\begin{tabular}{|c|c|c|c|c|c|c|c|c|c|c|c|c|c|c|}
\hline \multicolumn{7}{|c|}{ Boys } & \multirow{3}{*}{ Year } & \multicolumn{7}{|c|}{ Girls } \\
\hline \multicolumn{2}{|c|}{ total } & \multicolumn{2}{|c|}{ pre-school } & \multicolumn{2}{|c|}{ school } & \multirow{2}{*}{$P^{*}$} & & \multicolumn{2}{|c|}{ total } & \multicolumn{2}{|c|}{ pre-school } & \multicolumn{2}{|c|}{ school } & \multirow{2}{*}{$P^{*}$} \\
\hline $\bar{x}$ & $s$ & $\bar{x}$ & $s$ & $\bar{x}$ & $s$ & & & $\bar{x}$ & $s$ & $\bar{x}$ & $s$ & $\bar{x}$ & $S$ & \\
\hline 23.8 & 4.5 & 23.4 & 4.0 & 24.1 & 4.7 & 0.0027 & 2005 & 23.3 & 4.5 & 23.3 & 4.1 & 23.3 & 4.7 & 0.9612 \\
\hline 23.9 & 4.7 & 23.8 & 4.5 & 23.9 & 4.7 & 0.6508 & 2006 & 23.1 & 4.3 & 23.1 & 4.1 & 23.2 & 4.3 & 0.5997 \\
\hline 24.2 & 4.6 & 24.3 & 4.4 & 24.1 & 4.7 & 0.4340 & 2007 & 23.4 & 4.3 & 23.3 & 3.9 & 23.5 & 4.5 & 0.6549 \\
\hline 23.9 & 4.6 & 24.0 & 4.5 & 23.8 & 4.6 & 0.3820 & 2008 & 23.2 & 4.3 & 23.2 & 4.1 & 23.2 & 4.4 & 0.8936 \\
\hline 23.9 & 4.5 & 23.9 & 4.5 & 23.9 & 4.6 & 1.0000 & 2009 & 23.2 & 4.4 & 23.3 & 4.4 & 23.1 & 4.4 & 0.3810 \\
\hline 23.9 & 4.6 & 23.9 & 4.4 & 24.0 & 4.7 & 0.3905 & $\begin{array}{c}\text { total } \\
2005-2009\end{array}$ & 23.3 & 4.4 & 23.3 & 4.1 & 23.2 & 4.5 & 0.9741 \\
\hline
\end{tabular}

Tab. 3. Numerical description of body height in boys and girls

\begin{tabular}{|c|c|c|c|c|c|c|c|c|c|c|c|c|c|c|}
\hline \multicolumn{7}{|c|}{ Boys } & \multirow{3}{*}{ Year } & \multicolumn{7}{|c|}{ Girls } \\
\hline \multicolumn{2}{|c|}{ total } & \multicolumn{2}{|c|}{ pre-school } & \multicolumn{2}{|c|}{ school } & \multirow{2}{*}{$P^{*}$} & & \multicolumn{2}{|c|}{ total } & \multicolumn{2}{|c|}{ pre-school } & \multicolumn{2}{|c|}{ school } & \multirow[b]{2}{*}{$P^{*}$} \\
\hline $\bar{x}$ & $s$ & $\bar{x}$ & $s$ & $\bar{x}$ & $s$ & & & $\bar{x}$ & $s$ & $x$ & $\boldsymbol{s}$ & $x$ & $S$ & \\
\hline 121.1 & 5.6 & 120.9 & 5.3 & 121.1 & 5.8 & 0.4732 & 2005 & 120.3 & 5.7 & 120.7 & 5.6 & 120.1 & 5.7 & 0.0365 \\
\hline 122.0 & 5.4 & 122.1 & 5.4 & 122.0 & 5.5 & 0.7057 & 2006 & 121.2 & 5.7 & 121.2 & 5.7 & 121.2 & 5.7 & 0.8877 \\
\hline 122.5 & 5.4 & 122.9 & 5.7 & 122.3 & 5.3 & 0.0665 & 2007 & 121.5 & 5.4 & 121.4 & 5.2 & 121.5 & 5.5 & 0.8955 \\
\hline 122.5 & 5.7 & 122.8 & 5.5 & 122.3 & 5.7 & 0.1563 & 2008 & 121.3 & 5.6 & 121.6 & 5.6 & 121.1 & 5.6 & 0.1045 \\
\hline 122.3 & 5.5 & 122.7 & 5.6 & 122.1 & 5.4 & 0.0430 & 2009 & 121.2 & 5.6 & 121.4 & 5.6 & 121.1 & 5.5 & 0.2302 \\
\hline 122.1 & 5.6 & 122.3 & 5.5 & 121.9 & 5.6 & 0.0152 & $\begin{array}{c}\text { total } \\
2005-2009\end{array}$ & 121.0 & 5.6 & 121.3 & 5.6 & 120.9 & 5.6 & 0.0246 \\
\hline
\end{tabular}

\footnotetext{
${ }^{1}$ Folds above biceps brachii, triceps brachii, below scapula and above the iliac spine
} 
Tab. 4. Numerical description of the body mass index in boys and girls

\begin{tabular}{|c|c|c|c|c|c|c|c|c|c|c|c|c|c|c|}
\hline \multicolumn{7}{|c|}{ Boys } & \multirow{3}{*}{ Year } & \multicolumn{7}{|c|}{ Girls } \\
\hline \multicolumn{2}{|c|}{ total } & \multicolumn{2}{|c|}{ pre-school } & \multicolumn{2}{|c|}{ school } & \multirow[t]{2}{*}{$D *$} & & \multicolumn{2}{|c|}{ total } & \multicolumn{2}{|c|}{ pre-school } & \multicolumn{2}{|c|}{ school } & \multirow{2}{*}{$P^{*}$} \\
\hline $\bar{x}$ & $s$ & $\bar{x}$ & $s$ & $\bar{x}$ & $s$ & & & $\bar{x}$ & $s$ & $\bar{x}$ & $s$ & $\bar{x}$ & $S$ & \\
\hline 16.2 & 2.2 & 15.9 & 2.0 & 16.3 & 2.2 & 0.0003 & 2005 & 16.0 & 2.1 & 15.9 & 2.0 & 16.1 & 2.2 & 0.2241 \\
\hline 16.0 & 2.2 & 15.9 & 2.1 & 16.0 & 2.3 & 0.3886 & 2006 & 15.7 & 2.0 & 15.6 & 1. & 15.7 & 2.0 & 0.4270 \\
\hline 16.0 & 2.1 & 16.0 & 2.0 & 16.0 & 2.2 & 0.9087 & 2007 & 15.8 & 2.1 & 15.8 & 2.0 & 15.8 & 2.2 & 0.8414 \\
\hline 15.8 & 2.0 & 15.8 & 2.0 & 15.8 & 2.1 & 0.6378 & 2008 & 15.7 & 2.0 & 15.6 & 1.8 & 15.7 & 2.1 & 0.2973 \\
\hline 15.9 & 2.1 & 15.8 & 2.0 & 15.9 & 2.2 & 0.1934 & 2009 & 15.7 & 2.0 & 15.7 & 2.0 & 15.7 & 2.1 & 0.7568 \\
\hline 16.0 & 2.1 & 15.9 & 2.0 & 16.0 & 2.2 & 0.0030 & $\begin{array}{c}\text { total } \\
2005-2009\end{array}$ & 15.8 & 2.1 & 15.7 & 1.9 & 15.8 & 2.1 & 0.1985 \\
\hline
\end{tabular}

Tab. 5. Numerical description of fat percentage in boys and girls

\begin{tabular}{|c|c|c|c|c|c|c|c|c|c|c|c|c|c|c|}
\hline \multicolumn{7}{|c|}{ Boys } & \multirow{3}{*}{ Year } & \multicolumn{7}{|c|}{ Girls } \\
\hline \multicolumn{2}{|c|}{ total } & \multicolumn{2}{|c|}{ pre-school } & \multicolumn{2}{|c|}{ school } & \multirow{2}{*}{$P^{*}$} & & \multicolumn{2}{|c|}{ total } & \multicolumn{2}{|c|}{ pre-school } & \multicolumn{2}{|c|}{ school } & \multirow{2}{*}{$P^{*}$} \\
\hline$x$ & $s$ & $\bar{x}$ & $s$ & $\bar{x}$ & $s$ & & & $\bar{x}$ & $s$ & $\bar{x}$ & $s$ & $\bar{x}$ & $S$ & \\
\hline 16.2 & 6.9 & 15.7 & 6.1 & 16.4 & 7.2 & 0.0360 & 2005 & 19.4 & 5.9 & 19.2 & 5.5 & 19.5 & 6.1 & 0.3658 \\
\hline 15.5 & 7.9 & 15.5 & 7.8 & 15.5 & 8.0 & 0.9487 & 2006 & 18.4 & 5.9 & 18.4 & 6.1 & 18.4 & 5.8 & 0.9688 \\
\hline 16.2 & 8.4 & 16.2 & 7.9 & 16.1 & 8.6 & 0.8529 & 2007 & 18.8 & 6.2 & 18.8 & 5.8 & 18.8 & 6.3 & 0.9997 \\
\hline 15.3 & 7.0 & 15.2 & 6.7 & 15.3 & 7.2 & 0.7755 & 2008 & 18.5 & 5.5 & 18.1 & 5.0 & 18.7 & 5.8 & 0.0647 \\
\hline 14.8 & 6.1 & 14.5 & 6.1 & 15.0 & 6.1 & 0.1608 & 2009 & 18.1 & 5.3 & 18.3 & 5.3 & 18.0 & 5.4 & 0.4278 \\
\hline 15.6 & 7.3 & 15.4 & 6.9 & 15.7 & 7.5 & 0.1165 & $\begin{array}{c}\text { total } \\
2005-2009\end{array}$ & 18.7 & 5.8 & 18.6 & 5.6 & 18.7 & 5.9 & 0.3884 \\
\hline
\end{tabular}

No statistically significant differences in the level of body mass between children from pre-schools and schools in the years 2005-2009 were noted. When calculations were made for each year separately, the differences were revealed in boys in 2005 exclusively. This year boys attending school were characterized by significantly higher body mass. Children from schools were taller than peers from pre-schools when calculations were made for all years altogether. When calculations were made for each year separately, the differences were revealed in boys in 2009 and in girls in 2005. Significant differences in body mass indices were noted in boys exclusively. Higher values appeared in boys from "0 school classes" in 2005 and in calculations considering all years altogether.

Fat deposition reflected by \%BF was significantly higher in boys from schools also in 2005 exclusively. In girls substantial differences in values of fat percentage were not noted.

Tab. 6. Numerical description of the results of sit and reach in boys and girls

\begin{tabular}{|c|c|c|c|c|c|c|c|c|c|c|c|c|c|c|}
\hline \multicolumn{7}{|c|}{ Boys } & \multirow{3}{*}{ Year } & \multicolumn{7}{|c|}{ Girls } \\
\hline \multicolumn{2}{|c|}{ total } & \multicolumn{2}{|c|}{ pre-school } & \multicolumn{2}{|c|}{ school } & \multirow{2}{*}{$P^{*}$} & & \multicolumn{2}{|c|}{ total } & \multicolumn{2}{|c|}{ pre-school } & \multicolumn{2}{|c|}{ school } & \multirow{2}{*}{$P^{*}$} \\
\hline $\bar{x}$ & $S$ & $\bar{x}$ & $s$ & $\bar{x}$ & $S$ & & & $\bar{x}$ & $s$ & $\bar{x}$ & $s$ & $\bar{x}$ & $s$ & \\
\hline 19.7 & 5.6 & 19.6 & 5.5 & 19.7 & 5.7 & 0.6845 & 2005 & 21.7 & 5.3 & 21.7 & 5.4 & 21.7 & 5.2 & 0.8845 \\
\hline 20.7 & 5.2 & 20.6 & 4.7 & 20.8 & 5.4 & 0.5720 & 2006 & 23.0 & 4.6 & 23.2 & 4.5 & 22.9 & 4.7 & 0.2615 \\
\hline 21.5 & 5.1 & 21.4 & 4.9 & 21.6 & 5.3 & 0.4577 & 2007 & 23.8 & 4.7 & 23.9 & 4.6 & 23.8 & 4.8 & 0.5967 \\
\hline 20.6 & 5.6 & 20.4 & 5.4 & 20.7 & 5.8 & 0.4069 & 2008 & 23.2 & 5.0 & 23.1 & 4.8 & 23.3 & 5.1 & 0.5258 \\
\hline 19.5 & 6.1 & 19.7 & 6.0 & 19.4 & 6.1 & 0.4393 & 2009 & 22.8 & 5.5 & 23.0 & 5.5 & 22.7 & 5.6 & 0.2583 \\
\hline 20.5 & 5.6 & 20.3 & 5.4 & 20.4 & 5.7 & 0.3998 & $\begin{array}{c}\text { Total } \\
2005-2009\end{array}$ & 22.9 & 5.1 & 22.9 & 5.0 & 22.8 & 5.1 & 0.4012 \\
\hline
\end{tabular}


Tab. 7. Numerical description of the results of standing broad jump in boys and girls

\begin{tabular}{|c|c|c|c|c|c|c|c|c|c|c|c|c|c|c|}
\hline \multicolumn{7}{|c|}{ Boys } & \multirow{3}{*}{ Year } & \multicolumn{7}{|c|}{ Girls } \\
\hline \multicolumn{2}{|c|}{ total } & \multicolumn{2}{|c|}{ pre-school } & \multicolumn{2}{|c|}{ school } & \multirow{2}{*}{$P^{*}$} & & \multicolumn{2}{|c|}{ total } & \multicolumn{2}{|c|}{ pre-school } & \multicolumn{2}{|c|}{ school } & \multirow{2}{*}{$P^{*}$} \\
\hline $\bar{x}$ & $s$ & $\bar{x}$ & $s$ & $\bar{x}$ & $s$ & & & $\bar{x}$ & $s$ & $\bar{x}$ & $s$ & $x$ & $s$ & \\
\hline 105.6 & 16.7 & 105.6 & 16.5 & 105.7 & 16.8 & 0.9097 & 2005 & 100.7 & 16.1 & 101.8 & 15.3 & 100.2 & 16.5 & 0.0619 \\
\hline 108.4 & 15.6 & 108.6 & 14.6 & 108.3 & 16.0 & 0.7538 & 2006 & 103.5 & 14.4 & 105.7 & 13.5 & 102.5 & 14.7 & 0.0000 \\
\hline 108.5 & 14.8 & 108.1 & 15.1 & 108.7 & 14.6 & 0.4588 & 2007 & 103.5 & 14.3 & 104.5 & 13.7 & 103.0 & 14.6 & 0.0646 \\
\hline 111.1 & 19.1 & 113.2 & 18.9 & 109.8 & 19.0 & 0.0007 & 2008 & 107.5 & 16.7 & 110.7 & 16.3 & 105.8 & 16.6 & 0.0000 \\
\hline 109.5 & 16.3 & 110.7 & 15.4 & 108.8 & 16.9 & 0.0431 & 2009 & 107.4 & 15.0 & 109.3 & 13.8 & 106.5 & 15.5 & 0.0010 \\
\hline 108.6 & 16.7 & 109.3 & 16.5 & 108.2 & 16.8 & 0.0070 & $\begin{array}{c}\text { total } \\
2005-2009\end{array}$ & 104.4 & 15.6 & 106.3 & 15.0 & 103.5 & 15.8 & 0.0000 \\
\hline
\end{tabular}

Tab. 8. Numerical description of the results of sit-ups in boys and girls

\begin{tabular}{|c|c|c|c|c|c|c|c|c|c|c|c|c|c|c|}
\hline \multicolumn{7}{|c|}{ Boys } & \multirow{3}{*}{ Year } & \multicolumn{7}{|c|}{ Girls } \\
\hline \multicolumn{2}{|c|}{ total } & \multicolumn{2}{|c|}{ pre-school } & \multicolumn{2}{|c|}{ school } & \multirow{2}{*}{$P^{*}$} & & \multicolumn{2}{|c|}{ total } & \multicolumn{2}{|c|}{ pre-school } & \multicolumn{2}{|c|}{ school } & \multirow{2}{*}{$P^{*}$} \\
\hline $\bar{x}$ & $s$ & $\bar{x}$ & $s$ & $\bar{x}$ & $s$ & & & $\bar{x}$ & $s$ & $\bar{x}$ & $s$ & $\bar{x}$ & $s$ & \\
\hline 12.7 & 5.3 & 12.9 & 5.0 & 12.7 & 5.4 & 0.5577 & 2005 & 13.2 & 4.8 & 13.2 & 4.9 & 13.2 & 4.8 & 0.8240 \\
\hline 14.1 & 4.9 & 13.6 & 5.3 & 14.3 & 4.8 & 0.0196 & 2006 & 13.9 & 4.6 & 13.9 & 4.4 & 13.9 & 4.6 & 0.8563 \\
\hline 14.6 & 4.5 & 14.7 & 4.5 & 14.6 & 4.5 & 0.6936 & 2007 & 14.2 & 4.2 & 14.5 & 4.0 & 14.0 & 4.3 & 0.0234 \\
\hline 13.4 & 5.2 & 14.0 & 5.2 & 13.0 & 5.1 & 0.0001 & 2008 & 13.2 & 4.8 & 13.9 & 4.7 & 12.9 & 4.8 & 0.0001 \\
\hline 13.3 & 5.1 & 13.3 & 5.4 & 13.3 & 5.0 & 0.9845 & 2009 & 13.8 & 4.7 & 13.7 & 5.1 & 13.8 & 4.5 & 0.6040 \\
\hline 13.6 & 5.1 & 13.7 & 5.1 & 13.6 & 5.0 & 0.2437 & $\begin{array}{c}\text { total } \\
2005-2009\end{array}$ & 13.6 & 4.6 & 13.8 & 4.7 & 13.5 & 4.6 & 0.0168 \\
\hline
\end{tabular}

Tab. 9. Numerical description of post-effort HR in boys and girls

\begin{tabular}{|c|c|c|c|c|c|c|c|c|c|c|c|c|c|c|}
\hline \multicolumn{7}{|c|}{ Boys } & \multirow{3}{*}{ Year } & \multicolumn{7}{|c|}{ Girls } \\
\hline \multicolumn{2}{|c|}{ total } & \multicolumn{2}{|c|}{ pre-school } & \multicolumn{2}{|c|}{ school } & \multirow{2}{*}{$P^{*}$} & & \multicolumn{2}{|c|}{ total } & \multicolumn{2}{|c|}{ pre-school } & \multicolumn{2}{|c|}{ school } & \multirow{2}{*}{$P^{*}$} \\
\hline $\bar{x}$ & $s$ & $x$ & $s$ & $\bar{x}$ & $s$ & & & $\bar{x}$ & $s$ & $x$ & $s$ & $x$ & $s$ & \\
\hline 113.1 & 14.0 & 112.2 & 13.6 & 113.7 & 14.3 & 0.0693 & 2005 & 121.9 & 16.1 & 120.8 & 15.4 & 122.6 & 16.5 & 0.0485 \\
\hline 112.5 & 13.7 & 111.2 & 12.8 & 113.2 & 14.1 & 0.0121 & 2006 & 119.0 & 14.6 & 117.9 & 13.2 & 119.6 & 15.1 & 0.0613 \\
\hline 110.9 & 15.0 & 109.5 & 13.6 & 111.8 & 15.7 & 0.0079 & 2007 & 117.6 & 15.1 & 116.1 & 13.7 & 118.4 & 15.8 & 0.0080 \\
\hline 111.8 & 12.9 & 112.0 & 12.8 & 111.7 & 12.9 & 0.7191 & 2008 & 119.5 & 14.2 & 118.5 & 13.6 & 120.1 & 14.5 & 0.0607 \\
\hline 111.9 & 12.8 & 110.9 & 12.5 & 112.6 & 13.0 & 0.0287 & 2009 & 119.5 & 14.3 & 120.4 & 15.0 & 119.0 & 13.9 & 0.0993 \\
\hline 112.2 & 14.3 & 111.0 & 13.4 & 112.9 & 14.7 & 0.0000 & $\begin{array}{c}\text { total } \\
2005-2009\end{array}$ & 119.6 & 15.4 & 118.3 & 14.3 & 120.2 & 15.9 & 0.0002 \\
\hline
\end{tabular}

There were no statistically significant differences between children from pre-schools and schools in the results of sit and reach (Table 6).

In standing broad jump tests children from pre-schools achieved characteristically higher results in the observations carried out in all years altogether; and when studied separately, the results were higher in 2008 and 2009 in both boys and girls, and only in girls in 2006 (Table 7). Statistically significant differences were noted in sit-ups. Boys from schools achieved higher scores in 2006 and from pre-schools in 2008. Girls from pre-schools got higher scores in 2007 and 2008, and altogether in the years 2005-2009 in comparison with peers from schools (Table 8 ). In children from pre-schools lower values of arithmetic means in post-effort HR were observed in all years altogether and separately in 2006, 2007, 2009 in boys and 2005, 2007 in girls (Table 9).

\section{Discussion}

The purpose of the study was to compare the level of physical development and physical fitness in 6-year-old children learning at schools and pre-schools.

In children attending pre-schools in the years 2005-2009 higher values of body height were noted, and at the same time differences in body mass between children from pre-schools and schools were not found. Authors of nationwide research also revealed the tendency of achieving higher 
developmental parameters in children from pre-schools [10]. Children did not differ in the amount of fat deposition (\%BF) either. In the level of physical fitness the biggest differences between school and preschool subjects were noted in standing broad jump tests. Both boys and girls from pre-schools got higher scores in the test. This test is used in many modern set tests nowadays (EUROFIT, the International Test) and for 6-year-olds it is a coordination challenge as well as a trial assessing the children's strength and speed abilities [17]. Such diversification of the results, which is more beneficial for children from pre-schools, can be partially explained by somatic conditions. These children were taller, but many authors, demonstrating the relationship between body height and results in long jump test, simultaneously emphasize the low level of these correlations amongst the youngest children [18]. Forward sit and reach, commonly exercised as the measure of functional suppleness, is a component of fitness test in the conception of health-related-fitness [19]. The result in this test depends on the mobility of joints of the spine as well as body proportions and a range of motion of hips. The level of suppleness was similar in children from school and pre-school institutions. From the point of view of health it is necessary to assess suppleness parallel to the assessment of stabilization possibilities of the spine [20]. Applied in the research sit up test assesses strength endurance of the torso muscles and the test itself is also included in the conception of health-related fitness.

The diversity depending on the kind of educational institution appeared in our examinations in girls exclusively. Girls from pre-school "0" classes achieved a higher level of strength endurance of stomach muscles than their peers from schools. In boys, statistically significant differences in the years 20052009 were not observed. Shaping both suppleness and strength endurance of stomach muscles requires intentional exercises and it is impossible to expect advantageous changes in these aspects of physical fitness only in connection with everyday physical activity. Adaptive abilities for aerobic effort were revealed by step-test results, and more precisely, a reaction of the cardiovascular system on this submaximal effort. A higher level of these possibilities was observed in boys and girls from pre-school " 0 " classes in the years 2005-2009, and separately in 2006, 2007, 2009 in boys. A more beneficial result (lower post-effort HR) was seen in girls from pre-schools in 2005 and 2007. Results of this test are undoubtedly connected with everyday, also voluntarily undertaken, physical activity of the child. Since physical activity for 6-year-olds is an effect of a natural desire to exercise, creating appropriate conditions for such activity is very important. The report from nationwide research reveals a distinct diversification in undertaking physical activity between school and pre-school children, to the benefit of the latter [10].

\section{Conclusion}

It seems that observed differences in the level of physical fitness, especially its signs which depend on everyday physical activity, weigh in favor of conditions created for children in pre-schools.

\section{References}

1. Szuman S. Dojrzałość szkolna [in Polish] [School maturity]. Nowa Szkoła 1962;46:19.

2. Wolański N. Rozwój biologiczny człowieka [in Polish] [Biological development of a human being]. Warszawa: PWN; 1986.

3. Osiński W. Wielokierunkowe związki zdolności motorycznych i parametrów morfologicznych. Badania dzieci i młodzieży wielkomiejskiej z uwzględnieniem poziomu stratyfikacji społecznej[in Polish] [Multidirectional relationships between motor skills and morphological parameters. Studies on urban children and youth with consideration for the level of social stratification]. Poznań: AWF; 1988.

4. Przewęda R. Promocja zdrowia przez wychowanie fizyczne [in Polish] [Health promotion through physical education]. In: Karski J, editor. Promocja zdrowia [Promotion of Health]. Warszawa: IGNIS; 1999, 196-210.

5. Malina RM. Anthropology and Physical Activity: a Lifespan Perspective. Medicina Sportiva 2001;5:E69E75.

6. Kopczyńska-Sikorska J. O rozwoju dziecka w perspektywie auksologii [in Polish] [On child's development in view of auxology]. Kultura Fizyczna 2004;1-2:1-5.

7. Pawłucki A. Szkolna dojrzałość motoryczna dzieci 6- i 7-letnich a osiagnięcia ucznia klasy pierwszej [in Polish] [School maturity of 6- and 7-year-old children and achievements of a first-grade pupil]. Praca doktorska [PhD dissertation]. Warszawa: AWF; 1977.

8. Hurlock EB. Rozwój dziecka [in Polish] [Child's development]. Warszawa: PWN; 1985. 
9. Przetacznikowa M. Wiek przedszkolny [in Polish] [Pre-school age]. In: Żebrowska M, editor. Psychologia rozwojowa dzieci i młodzieży [in Polish] [Developmental psychology of children and youth]. Warszawa; 1972, 246.

10. Szumilas EM, editor. Sześciolatki w Polsce. Raport z badań 2006 [Six-year-olds in Poland. A report from studies 2006]. Kielce 2007.

11. Malinowski A. Pomiary somatometryczne [Somatometric measurements], (W:) Podstawy antropometrii [Basics of anthropometry], A.Malinowski i W.Bozziłow (red.), PWN 1997, 158-180.

12. Piechaczek H., Metody oceny składników tkankowych ciała [in Polish] [Methods of assessment of tissue components of the body]. (W:) Antropologia [Anthropology], AWF, Warszawa 1999.

13. Siri W.E. Body composition from the fluid spaces and density. Donner Lab. Med. Physic. (Univ. California), Report of March 1956, 19.

14. Durnin J., Rahaman M.M. The assessment of the amount of fat in the human body measurements of skinfolds thickness. British Journal of Nutrition 1967, 21, 681-684.

15. Kasch F.W. A comparison of the exercise tolerance of post-rheumatic and normal boys. Journal of the Association for Physical and Mental Rehabilitation 1961, 15, 35-40.

16. Kuntzleman Ch.T. Fitness Discovery Activities. Reston, AAHPERD 1990.

17. Radzińska M., Starosta W., Współzależność poziomu skoczności i koordynacji globalnej [in Polish] [A correlation between the level of jumping abilities and global coordination]. (W:) Znaczenie, rodzaje $\mathrm{i}$ struktura skoczności oraz jej uwarunkowania [Significance, types and structure of jumping ability and its determinants], Gorzów 2002, 170-175.

18. Żak S. Zdolności koordynacyjne dzieci i młodzieży z populacji wielkomiejskich na tle wybranych uwarunkowań somatycznych i aktywności ruchowej [in Polish] [Coordination skills of children and youth from urban populations in view of selected somatic determinants and motor activity]. Kraków: Wyd. Mon. AWF.

19. Bouchard C, Shephard RJ. Physical activity, fitness, and health: The model and key concepts. In: Bouchard C, Shephard RJ, Stephens T, editors. Physical Activity, Fitness, Health. Champaign: Human Kinetics; 1994, 77-88.

20. Stodolny J. Zespoły anatomiczno-czynnościowe kręgosłupa, ich funkcja i znaczenie w mechanizmach powstawania i profilaktyki przeciążeń [in Polish] [Anatomic-functional syndromes of the spine, their function and significance in the mechanisms of occurrence and prophylaxis of strains]. Medycyna Sportowa 2000;12:12-16. 